\title{
A philosophical interpretation of Deborah's understanding of justice in the Book of Judges
}

\author{
[Filosoficka interpretace chapani spravedlnosti u Debory v Knize \\ Soudcu]
}

Eva Vymetalova Hrabakova - Michal Podzimek - Beata Akimjakova

DOI: 10.18355/XL.2022.15.01.10

\begin{abstract}
The study deals with the issue of justice in the context of divine and natural law. The starting point is an analysis of selected texts from the Book of Judges, which are linked to Judge Deborah. The philosophical interpretation is based on the distinction between divine and natural law, with the main emphasis on the transcendent nature of both types of law. In the context of biblical interpretation, a judge is understood as a person who does not create law, only looks at natural law and listens to the voice of God, who reveals his will and his law. The judge, like the prophet, is the mediator between the transcendent space of God's being and will and between the immanent space of man's earthly existence. The study presents some ways of applying transcendental law in the daily practice of Israel and identifies possible problems with the current understanding of law, which is not tied to transcendent principles.
\end{abstract}

Key words: Natural law, God's law, Justice, Law, Deborah, Transcendence

\begin{abstract}
Abstrakt
Studie se věnuje problematice spravedlnosti v kontextu božského a přirozeného práva. Východiskem je analýza vybraných textů z Knihy Soudců, které se vážou na soudkyni Deboru. Filozofická interpretace vychází z rozlišení božího a přirozeného zákona, přičemž hlavní důraz je položený na transcendentní povahu obou typů práva. Soudce v kontextu biblické interpretace je chápán jako osoba, která právo netvoří, pouze nahlíží na přirozený zákon a naslouchá hlasu Boha, který zjevuje svou vůli a svůj zákon. Soudce, podobně jako prorok, je prostředníkem mezi transcendentním prostorem Božího bytí, vůle a mezi imanentním prostorem pozemské existence člověka. Studie prezentuje některé způsoby uplatňování transcendentního zákona v každodenní praxi Izraele a identifikuje možné problémy současného chápání práva, které není vázáno na transcendentní východiska.

Klíčová slova: Přirozený zákon, Boží zákon, Spravedlnost, Právo, Debora, Transcendence

„Shledal jsem, že není nic lepšiho, než když se člověk raduje z toho, co koná, nebot' to je jeho podil. Kdo mu dá nahlédnout, co se stane po něm?" (Kaz 3,22 )

„Kdo může vědět, co je člověku v životě $k$ dobru, $v$ časných dnech jeho pomíjivého žití, jež jako stín mu plynou? Kdo oznámí člověku, co pod sluncem nastane po něm? "(Kaz 6,12)
\end{abstract}




\section{Úvod}

Filozofický koncept pojmu spravedlnosti je založený na předpokladu existence zákona nebo normy, kterou lze použít, jako míru ve smyslu měření. Norma je pravidlo pomocí kterého zjišt'ujeme, zda je něčeho přiměřena, nebo je něčeho málo, nebo naopak je navýšená (Pavlikova, 2019). Platnost normy je odvozena od toho, do jaké míry je respektována resp. do jaké míry je možné její respektování vynutit. Platnost určité normy je také dané tím, kdo je autoritou, která normu vynáší. Za autoritu považujeme ve všeobecnosti někoho, kdo se v normované oblasti vyzná, kdo zná její míru a ví, co je nejlepší v dané oblasti dělat (Roubalova et al., 2021b: 120).

Spravedlnost je v různých filozofických systémech, zejména východních, odvozená od harmonie, podobně, jako je tomu v židovské, řecké a následně křest'anské tradici (Akimjak, 2015). Východní harmonie je spravedlností kosmu (Ortega-Villasenor, 2021a). Kosmos a jeho dění probíhá jako proces, kterého nekonečným cílem je vyrovnávání a harmonizace (Maturkanic at al., 2021). Narušení harmonie se může dít různými způsoby. Může jít o vysloveně náboženský akt, člověk se zapomene pomodlit, nebo přinést obět' či se rituálně očistit. Narušení harmonie může mít i podobu konání zla, ubližování druhému člověku, lhaní nebo týraní zviŕăa či znečišt'ováni životního prostředí. Všechny skutky člověka nějakým způsobem ovlivňují jeho budoucnost a budoucnost ostatních. Když člověk koná spravedlivě, může očekávat, že i s ním bude nakládáno podobně. Dosáhne věčnou blaženost, vymaní se z koloběhu znovuzrození, bude mít hodně potomků, majetek apod. Naopak nespravedlivého čeká úděl trestu, trest je způsob, jak navrátit harmonii zpět. Aby však posouzení skutků bylo nestranné, musí být zákon anebo norma, která je transcendentní, nezávislá od vůle člověka a určuje míru konání a nestranný musí být také ten, kdo měří, teda soudce (Roubalova et al., 2021d: 59).

\section{Pojem spravedlnosti - hebrejsky $c^{e} d a k a$; řecky dikaiosyné}

Státní normy a také etické normy mají svůj prototyp v náboženských normách, které zejména $\mathrm{v}$ židovské tradici $\mathrm{v}$ sobě integrovali a integrují normativitu božského zákona, normy pro sociální chovaní, normy pro chování k cizincům, k rodinným příslušníkům ale i ke zvířatům a prírodě (Tkacova et al., 2021; Budayova, 2021; Janigova et al., 2021). Božský zákon určuje normy pro lidské chování. To, co se děje v limitě normy je normální. To, co je normální je v souladu s právem a zákonem, je to právně v pořádku a to, co je správné, je vlastně pravdivé a spravedlivé.

Pojmy cedek, $c^{e} d a k a$ a cadik se odvozují od hebrejského kořene $c$ - $d$-k, který vyjadřuje: „být zákonný“ ale také „vědomý“ (Gesenius, 1962: 673 - 675; Pípal, 2006: 143). Slovo cadik se nejlépe překládá jako „být rovný“, což je obecně sekulární pojem, jenž získává nové souvislosti a nabývá specifického významu v Bibli. Pro účely tohoto pojednání se zaměříme na Tanach, jmenovitě pak zejména vybranou pasáž knihy Soudců. V Tanachu výše uvedenými pojmy nejsou vyjádřeny jen rovné lidské vztahy, ale také a zejména přirozenost a vůle Boží.

„S Spravedlivý je Hospodin na všech svých cestách... “ (Ž 145, 17). Jde o „vlastnost (atribut) Boha, který zajištuje rád a garantuje právo“ (Beneš 2020: 127). Maskulinní pojem cadik se objevuje v Bibli 118 krát a femininní výraz spravedlnost 156 krát. Spravedlnost odpovídá záměru Boží cesty, koresponduje s vírou v Boha a dá se též charakterizovat jako poctivost. (Gn 15; 18, 30). Pojem zahrnuje tři aspekty osobních

XLinguae, Volume 15 Issue 1, January 2022, ISSN 1337-8384, eISSN 2453-711X 
vztahů: etický, výzkumně-popisný a teokratický. „Spravedlnost je jen tam, kde se vše děje v souladu s Hospodinem“ (Benes, 2012: 73).

Tanach líčí spravedlivého jako toho, který slouží Hospodinu (Mal 3, 18), a to v každé životní situaci a fázi, kdy jedná čestně vůči okolí i sobě samému, což ilustrativně potvrzuje text k Jobovi (Jb 29, 12-15). Rovnost, jež je synonymem pro spravedlnost, spočívá v poslušnosti Božího zákona a shodě s božskou přirozeností. Spravedliví lidé povznáší úroveň národa a vzpomínka na spravedlivého je požehnáním pro lid (Jancovic, 2019). Opisem pro následování Boha je biblický výrok, že ve městě přebývá spravedlnost. (Iz 1, 21). Zdrojem spravedlivého jednání je předání Boží spravedlnosti do rukou jeho lidu (Ž 72, 1-2). Proroci volají po spravedlnosti, Amos volal po spravedlnosti v branách (Am 5,$15 ; 24) . ., A m$ 5,14-15 je závěrem velmi ostré a výrazné sociálni kritiky“ (Beneš 2019: 120). Proroci se dovolávají správného, tedy rovného fungování veřejných institucí. Kritizují i zkaženou, tedy nečestnou náboženskou praxi (Am 5, 23-24).

Proces přetváření a oplodnění země spravedlností je vyjádřen spojením setí ve spravedlnosti, a sklízením v milosrdenství $(\mathrm{Oz} 10,12)$. Spravedlnost je prvním krokem k přijetí druhého člověka, tím druhým krokem je milosrdenství. Odpouštění toho, co nelze napravit nebo pouze napravit jen s obtížemi. Spravedlivé chování je projevem dobrého srdce (Ez 36, 25-27). Závažný teologický obrat spravedlivý bude žit z viry" (Hab 2,4) poukazuje na to, že víra v to, že Bůh proměňuje lidskou bytost ve spravedlivého člověka, dává smysl života a otevírá cestu k budoucí záchraně. Spravedlnost přivádí k pokoji a je dílem Ducha (Iz 32, 15-17). Obraz spravedlnosti a pokoje, jež se vzájemně políbily, (Ž 85,10$)$ je patrně výjevem pro smírení mezi Bohem a člověkem. Biblická etika má usilovat o naplňování Boží spravedlnosti ve společnosti. Spravedlnost se staví proti lži a vždy vítězí nad znehodnocováním člověka. Důsledkem promýšlení Boží spravedlnosti je výpověd' resp. antropologickoteologická úvaha o ospravedlnění (Iz 1,27; 46, 13). Ospravedlnění totiž přináší člověku spásu. Bůh se charakterizuje jako spravedlivý, když vysvobozuje svůj lid (Iz 42, 6; 45, 13). Boží spravedlnost spočívá v soudu, věrnosti a lásce (Ž 36, 6-7). Spravedlnost má své teokratické vyjádření ve vztahu Hospodina a jeho národa. Z biblických výroků je zřejmé, že Hospodinova spravedlnost se ukáže na osvobození jeho lidu (Iz 45, 21).

Důsledkem nevěry Hospodinova lidu, tedy selhání ve smluvní věrnosti jsou postihy. Proto spravedlivé je poučit a vychovat lid tak, aby se vrátil k Hospodinu, narovnal své jednání a chování. Př́ikladem nápravy je model trpícího Božího služebníka, který ruku spravedlnosti nese sám na sobě (Iz 53). V tom všem je zřejmé, že pojetí spravedlnosti v Tanachu není neosobní a samoúčelné, nýbrž vede k pomoci a záchraně (Roubalova et al., 2021c).

\section{Biblické pojetí spravedlnosti a práva}

Spravedlnost není možné oddělit od práva, jak již bylo v úvodu řečeno. V biblickém pojetí spravedlnosti a práva je významným faktem to, že jediným zákonodárcem je Bůh (Hlad, 2021a: 130). Člověk, at' už je to král nebo prorok je pouze nástrojem $\mathrm{v}$ rukách Boha, přináší zákon, který dává Bůh. Zákon a z něj vyplývající právo jsou vyjádřením Boží vůle a jejich dodržováním se stává člověk spravedlivým. Vzhledem $\mathrm{k}$ různosti okolních kmenů a národů, ale i vzhledem k dynamickým změnám $\mathrm{v}$ dějinách Izraele dochází občas $\mathrm{k}$ pochybnostem o tom, kdo je svrchovaným 
zákonodárcem. To nastává zejména tehdy, když dochází k oddělování božské a lidské dimenze v celku právních norem. Jinak řečeno, když si Izraelité, alespoň někteří mysleli, že Boží zákon platí jen pro určité oblasti života a v jiných oblastech rozhodují sami o své existenci. Takové přesvědčení nezrrídka skončilo katastrofou v podobě porážky anebo zajetí či okupace.

Dá se vůbec v biblickém textu Tanachu nalézt vymezení posvátného práva, tedy práva od Boha a světského práva, tedy práva bez Boha? To z hlediska ontologické součinnosti Boha a člověka není možné. Jediné rozdělení, které na základě biblických textů známe, je rozdělení na právo apodiktické: platí vždy a všude a kazuistické: platí za určitých podmínek a okolností. Boží právo udržuje člověka na živu, zachraňuje a řeší jeho situaci zvenčí. Dochází tedy k procesu, vedoucímu k juridizaci náboženství a etizaci práva, což lze dobře zkoumat v oblasti sociologie náboženství (Berger, 1998). V mýtickém diskursu se jedná o provázanost symbolu slunce $\mathrm{s}$ Bohem, který $\mathrm{v}$ zosobnění slunce zpřítomňuje stránku permanentního osvětlování pravé podoby všech věcí, tedy spravedlivého zacházení se stvořením. Bůh jako slunce propátrá a prozkoumá vše, čímž zabezpečuje objektivitu při vyslovení spravedlivého soudu nad stvořením, nad udržením řádu a varuje před vpádem chaosu. Prosazování spravedlnosti tak vede k opakované záchraně před zkázou uspořádaného světa.

Zatímco v polyteistických náboženstvích narušuje řádný běh světa soupeření a souboj jednotlivých božstev, do něhož vstupuje sluneční bůh se smírčím poselstvím, v biblickém, respektive tanachickém náboženství, se proti světovému uspořádání a daným pravidlům brání stvoření samo. Odporuje mu tím, že se snaží odpoutat od nároků Boha Zákonodárce a Soudce zároveň (Keel, Uehlinger, 1998). Pozemští soudci, at' už se jednalo o určitou skupinu, jež byla pověřena $v$ dávné minulosti vedením izraelských kmenů, nebo o krále coby soudce, či soudce v úloze zvláštních panovníkových pověřenců, ti všichni přijímají účast na Hospodinově soudcovské úloze. Jejich rozhodnutí je tedy vázáno na poslušnost vůči Bohu a má být v souladu s Božími nařízeními, která jsou s ohledem na konkrétní situaci vykládána a aplikována v praxi. Soudcové mají mít vhled jako slunce. Nikoliv náhodou jeden ze soudců, dávných charismatických vůdců, nese jméno Šimšon (Sluníčko). V Bibli a rabínské literatuře je vztah mezi lidským soudem a božskou spravedlností popsán jako dvě na sobě závislé veličiny či spojené nádoby. Bůh zmocňuje soudce, kteří vykonávají spravedlnost (Shapira, 2012: 273).

Když ve společnosti dochází k nárůstu nespravedlnosti, je to znakem toho, že se zvyšuje autonomní legislativní aktivita, která vyvolený národ vzdaluje od práva a zákona Boha a lidé se řídí vlastním lidským zákonem. Taková situace se může projevit chaosem uvnitř společnosti, může se projevit jako ignorování vlastních kulturních hodnot Izraele a přijímaní cizích hodnot včetně bohů, anebo se může projevit jako blížící se sociální a politický kolaps (Akimjak, 2006; Ortega-Villasenor, 2021b). Změnu v nastoleném kursu je možné vykonat bud' tak, že se lidé zavčas vzpamatují anebo že dojde ke katastrofě, která způsobí ohrožení samotné existence národa. A jsou to právě soudci, kteří upozorňují na odklon od Božího zákona. Jsou to soudci, kdo hledí na Boží zákon i na zákon lidský a soudí, když už je lidský zákon v rozporu s božím zákonem, kdy dochází k narušení spravedlnosti vracející se vyvolený národ zpátky na cestu $\mathrm{k}$ Bohu.

XLinguae, Volume 15 Issue 1, January 2022, ISSN 1337-8384, eISSN 2453-711X 


\section{Spravedlnost jako projev božího a lidského jednání v Knize Soudců}

Ve zmiňovaném spise se podle obvyklých referencí objevuje soulad mezi působením Boží spravedlnosti v soudním procesu a lidského soudního rozhodování. Soudci nesou prorockou a kněžskou roli, což je zřejmé v explicitním provázání s Hospodinovou intervencí, ale zároveň jsou vůdci lidu, kteří uspořádávají ústní právní zvyklosti, jež obvykle označujeme jako nepsané právo (Shapira, 2012: 273).

Posvátný řád se vtěluje do společenského uspořádání; jde o zavedení pořádků Hospodina, Boha Izraele (Craig, 2017). Samozřejmě, že veškeré počínání stěžejních postav knihy Soudců lze vnímat i jako druhotné legitimizování svatých bojů a prosazování menších etnik, jež by bez agilního a statečného vůdce nenašly mezi pevnými královstvími a obrovskými ř́šemi zastání. Ruku vůdců utlačovaných, tedy víc než $\mathrm{v}$ př́ípadě těch mocných $\mathrm{v}$ zemi, vede Hospodin.

Celým spisem se prolíná stále se opakující výrok: ,v věch dnech neměli v Izraeli krále, každý dělal, co uznal za správné. “Sd 1, 1-20; 22-26 (Craig, 2017: 14).

Soudci jsou Bohem povolanými agenty, kterým je svěřen úkol uskutečňovat soud (Webb, 2012). Soudcové se též stali mluvčími v době krize. (Craig, 2017: 14) Rovněž kniha Rut, příběh jedné rodiny, jíž se ujímá Hospodin přes zachránkyně Noemi-Rut, záměrně situovaná do doby soudců, tematicky odpovídá realizaci Boží spravedlnosti ve víře a lásce komunity, jež je součástí Hospodinova lidu. Noemi i Rut jsou prostřednicemi Boží spravedlnosti uprostřed lidu Izraele (Craig, 2017: 15), a tak v tomto smyslu vhodně doplňují soudce, nebot' představují onen lid am haarec, který je třeba ochránit či zachránit. Obratem ,za dob soudcování soudců“ je upřednostněno místo nositelů spravedlnosti do lokálních podmínek a aktuálních politických a společenských poměrů. Soudci vystupují v rámci pravidelných cyklů, kdy dochází odpadnutí (úpadku víry), útlaku, povolání soudce Hospodinem, vysvobození, míru, úpadku (Craig, 2017: 34).

Z hlediska rétorické kritiky je dobré zmínit, že kompendium Soudců, oponující královské monarchii, představuje a proklamuje Hospodinův kult jako institut sociální spravedlnosti. Tolik např́iklad Robert Alter (Craig, 2017: 43). Ve spise Soudců se pracuje s narativní teologií, jež $\mathrm{v}$ každém př́iběhu vybraného soudce popisuje prosazování Boží spravedlnosti ve vítězství jeho lidu. Ve spise se prolínají deuteronomistické zásady a jazyková artikulace $(2,1-5 ; 6,7-10 ; 10,11-14)$, ale také individuální narativ o soudu (3, 7-16,31; Craig, 2017: 53). Násilí v knize Soudců, pochopitelně ve svaté válce, velmi komplikuje jednoduché pojetí Boží spravedlnosti. Svatá válka vede v souladu s nárokem Boží spravedlnosti ke zničení všeho, co bylo boji získáno. Je to vyjádřeno hebrejským slovesem ch - r- m -- klaté, tedy určené pro Hospodina, propadlé Bohu.

Kniha Soudců ukazuje na důležitý aspekt racionalizace př́stupu Izraelitů k Bohu. Racionalizace jako proces, kterým se vyvolený lid osamostatňuje, stává se dospělým a schopným užívat vlastní rozum a vlastní zkušenost. Je to cesta, ve které už nemusí Bůh každý následující krok svého lidu střežit. Lid je již dospělý a dostatečně moudrý na to, aby dokázal své kroky ř́ídit sám a aby prritom zůstal na cestě spravedlnosti. Může to být znakem, že Izrael je schopen přijímat také zákony, které jsou v souladu s Boží spravedlností, a zároveň dokáže kráčet s Bohem bez toho, aby jej Bůh vedl za ruku. Jak ukazuje nejen Kniha Soudců, ale celé dějiny Izraele, je to proces náročný a trvá až do dneška. Bůh ustanovuje ty, kteří mají čistou mysl, mysl, která není vázána na pozemská dobra ale je nasměrovaná k Boží transcendenci (Hlad, 2021b: 10). 
Takový člověk může vést vyvolený národ, a platí to pro jiné národy, směrem k budoucnosti, která má smysl. Pouze takový člověk může být soudcem, protože jedině takový muž je schopný dívat se nad aktuální problémy a moderní trendy a je schopný sledovat konečný cíl, završení dějin, ke kterému národ či národy směrují.

\section{Debořina píseň}

Debořina píseň jako politický zpěv je písní o Hospodinově vítězství a prosazení spravedlnosti. Je literární výpovědí, která obsahuje heroické prvky oslavující Boží spravedlnost, ale jako celek ji do hrdinské narativní literatury zařadit nemůžeme. Může se jednat o politicky laděnou píseň, která probouzí (hebrejsky: uri - vzhůru“) vědomí o absenci jednotného vládce a potřeby sjednocující záštity. V psané podobě tedy neprímo poukazuje $\mathrm{k}$ instituci, která byla $\mathrm{z}$ historického hlediska mnohem pozdějšího data, než pravděpodobný vznik Debořiny písně 12. - 11. st. př. n. 1 .

Prorocký potenciál v textu dosvědčuje Debořina exhortace: ,, uri, uri, Devora, uri, uri, davri šir", „Vzhůru, vzhůru, Deboro, vzhưru, vzhůru, promluv písní.“. (vlastní překlad). Soudce Šamgar mohl být vnímán jako prototyp válečníka, bojujícím pod praporem kenaanského válečného božstva. Šamgar mohl být vnímán jako prototyp válečníka, bojujícím pod praporem kenaanského válečného božstva.

Někteří badatelé usuzují, že tato píseň reflektuje mýtus o západosemitské bohyni lásky a války - Anat. Zatímco Anat je družka či milenka národů, Debora, žena Lapidotova, vystupuje jako matka Izraele. Debora je prorokyně, která patrně doprovází armádu svého lidu, aby jí mohla vybavit prorockým slovem pro rozhodný čas. Především však je mluvčí, vystupujícím ve jménu Hospodina - Boha Izraele. Promlouvá jako zvěstovatelka toho, co je v daných podmínkách vnímáno lidem Izraele jako spravedlivé. A tím je zastání se jednoho z neukotvených izraelských kmenů, vesnického - polonomádského obyvatelstva, tváŕí v tvář hrdým obyvatelům kenaanského města či městského státu. Její dílo taktéž souvisí s lidem, který ukrývá budoucí zdroje rozvoje a vymezení identity. Debořin příběh a píseň byly možná inspirovány poetickými texty, v nichž stěžejní aktérkou snad byla bohyně války, avšak jako je Anat zejména ugaritskou národní bohyní, tak i Debora ve své písni seznamuje s jedinečnou politickou a národně - náboženskou situací hebrejských kmenů. Debořina píseň krystalizuje z politické polemiky kenaanských obyvatel a hebrejského obyvatelstva. Debořin př́běh podle některých badatelů dokonce patrně předkládá zrcadlový obraz zavedených topografických modelů kenaanských božstev. Zatímco kenaanští bohové obvykle působí ze severu, v Debořině písni je Hospodin označen jako Bůh, který přichází opozičně z jihu (Sam, 2007: 9). Velkou pomocnicí a realizátorkou Debořina prorockého zření je Jáel, žena Kénijce Chebera. Také v textu zmiňovaný soudce Šamgar může představovat heroickou osobnost. V návaznosti na mnohem starší sumerské mýty z Isinu, př́běh soudce Šamgara vyjadřuje politickou pozici kmenů Izraele ve velmi staré době jejich vývoje. Nutno poznamenat, že o Šamgarovi se mluví formou poetické hyperboly. Je klidně možné, že Šamgar „Šamgar, ben Anat“, je jakýmsi prototypem osvoboditele od jiných národů a říśí, třeba Pelištejců i Egypta. Někteří badatelé dokonce tvrdí, že Debořina píseň je jakousi reimaginací Anatina ugaritského prŕiběhu spojeného se sluneční bohyní Šapaš, která velí své hvězdné armádě, jíž na výkonné úrovni vede Baraq - „blesk“ (La Montagne, 2019: 164-167). Je přitom jedna z hypostazí boha počasí, kterým Baal je. Odkaz na

XLinguae, Volume 15 Issue 1, January 2022, ISSN 1337-8384, eISSN 2453-711X 
sluneční symboliku je stvrzením osvobození z nadvlády jiného panství, v tomto případě nadvlády kenaanského krále Jabína a jeho koaličních partnerů.

\section{Sociální a politická analýza Debořiny písně}

Úsek v knize Soudců 5, 6-8 popisuje situaci v Izraeli před Debořiným vystoupením. Brandon Hurlbert se dokonce domnívá, že $\mathrm{v}$ textu můžeme pozorovat $\mathrm{z}$ ciziny vypůjčené nastolení spravedlivých řádů, nápadně se podobajících popisu vítězství faraona Merenptaha, jehož vojska na úrovni trestné výpravy pobořila kenaanská sídla a zotročila četné obyvatele (Hulbert, 2016). V Debořině písni se zračí zrcadlové nastolení spravedlnosti, jež spočívá v uznání práva slabšího, ale milovaného lidu uprostřed záplavy zdánlivě silných. Ukazuje, jak je síla relativním pojmem. Objevují se úvahy, že výroky uri ,vzhůru“ a qum ,povstaň“ jsou pravděpodobně historickým a liturgickým projevem a exhortací, odpovídající roli východosemitské bohyně Ištar v eposu o Tukulti Ninurtovi (Hulbert, 2016: 9). K aktivitě vybízející obsah 12. verše vede k přirovnání prorokyně Debory ke kněžce, reprezentující Hospodina na bitevním poli. Verše 13.-15a oslavují Hospodinovo zjevení, následující verše 15b-17 zpřítomňují vzkazy vůdcům ostatních kmenů a etnik. (Sd 5,13-17). Patrně mladším příspěvkem do textového rámce je smlouva vybraných kmenů o politické a vojenské solidaritě, kde jsou nedůvěryhodné kmeny Ruben, Gilead, Dan a Ašer popsány v prŕíkrém kontrastu vůči věrnosti kmenů Isachar, Zabulón a Neftalí. Tento popis poeticky sděluje, že správné a potažmo spravedlivé jednání není prosazováno všemi lidmi, i uvnitř sobě blízkých sociálních skupin, stejně, ale vždy je důsledkem statečného rozhodnutí a nasazení se pro jedno jediné. V našem případě se jedná o teokratický princip, vázaný na boha ze Seíru. To je Bůh, který je druhotně ztotožněn s Hospodinem a vyhlášen za Pána nad zmiňovanými kmeny - sociálními skupinami, nad národy a nakonec nad celým světem. Mluvčí vítězného boha je v písni Debora, matka, která prorokuje Izraeli dobrou budoucnost. Poetická pareneze se obrací k posluchačům a čtenářům se zřejmým pedagogickým zřetelem. Má je i do budoucna povzbuzovat k obdobnému jednání a nasazení pro Hospodinovu záležitost.

Debořina píseň je jednou z mnoha starých předovýchodních aktivizujících textů. Není však primárně historická, nýbrž polemická, jedinečným způsobem vypovídající o potlačení práva silnějšího a vítězství nepatrných a opomíjených - nomádů a žen. Existují i úvahy, podle nichž je pozorovatelné i naprosto odlišné genderové nastavení pozice žen $\mathrm{v}$ hebrejských kmenech (Debory) a v pasteveckých komunitách (Jáel) na jedné straně, a submisivních žen $\mathrm{z}$ měst, které jen pasivně očekávají př́íchod svých pánů a př́buzných na straně druhé (Lanoir a kol. 2009: 343). To je velmi kontrastní pojetí práva a vyvažuje opomíjení žen v právu jednat jménem svého lidu navenek aktivně a dokonce i akčně. Především však vyzdvihuje jasnou teologickou instrukci, kterou je sebevědomý lid, sjednocený v Hospodinově jménu. V tomto směru přesahuje Debořina skladba obvyklé vítězné písně (Hulbert, 2016).

\section{Závěr}

Nastolování spravedlivých řádů, i cestou svaté války, je jakousi přípravou pro čas příchodu izraelského království, které se objevuje jako nevyhnutelná společenská danost. Hospodinova spravedlnost však vrhá správné světlo na lidské pořádky v království (Roubalova et al., 2021a). Formou příběhů se zde pozoruhodně tříbí to, co díky druhotné reflexi badatelé označili jako Boží a přirozený zákon. V zaslíbené 
zemi a komunitě, vztahující na sebe tyto nároky, je vše nahlíženo z pozice Boží spravedlnosti. Debořina píseň, jako svědectví o soudkyni a ženě jdoucí do boje za spravedlnost, legitimitu nároků opomíjených vrstev obyvatelstva a vyřazovaných skupin, vše posiluje.

Jedná se o téma velice aktuální i pro současnou situaci v Izraeli a vztah izraelských občanů ke svým sousedům. Boží spravedlnost se paradoxně sekularizovala, ale jako normativ zůstává $\mathrm{v}$ podobě jedinečnosti národa a národního sebevědomí stále. Jeden ze současných judaistů $\mathrm{D}$. Biernot pak hovoři v této souvislosti o „izraelizaci“ (Biernot, 2016, 133nn) zejména té západní čili evropské společnosti (Kobylarek et al., 2021).

Podobně aktuální je i vztah mezi pozitivním a přirozeným právem. Tvorba zákonů v současnosti jakoby už nereflektovala potřebu opírat se o přirozený zákon, ani o zákon Boží. Důsledkem takového jednáni je stav, kde zákon prezentuje vůli zákonodárce, ne však vưli a hlavně potřeby těch, kterých se týká a kterých chování má upravovat. Zákon by mě vycházet $\mathrm{z}$ Božího zákona a přirozeného práva, které mají ve své podstatě ochranu důstojnosti lidské osoby a zabezpečení podmínek pro její seberealizaci (Kondrla, Durkova, 2018: 47; Jancovic, 2020). Zjednodušeně řečeno, zákon se musí dívat dál, za horizont dnešního dne, musí mít v sobě časovou reflexi budoucnosti. Pohled člověka, který se staví do role zákonodárce je však limitovaný. Z toho vyplývá, že při tvorbě zákonů musí vycházet $\mathrm{z}$ transcendentní povahy práva. To znamená, že člověk, který tvoří zákony je v pozici nástroje, pomocí kterého je zákon oznámen a nikoli samotným tvůrcem obsahu. Jak tomu bylo i v př́padě Debory.

\section{Bibliographic references}

Akimjak, A. (2006). Koncepcja filozofii kultury w ujęciu filozoficznej szkoły lubelskiej. Lublin: Norbertinum.

Akimjak, A. (2015). Sociálna filozofia. Levoča: MTM.

Bible. (1991). Písmo svaté Starého a Nového zákona včetně deuterokanonických knih. Český ekumenický překlad. Praha: Zvon.

Benes, J. (2019). Dvanáctka. Uvedení do Malých proroků. Praha: Návrat domů.

Benes, J. (2020). Pláč Jeremjášův. Praha: Advent-Orion.

Benes, J. (2012). Směrnice a řády. Praha: Advent-Orion.

Berger, P. (1998). Encylopedia of Religion and Society. Hartford: AltaMira.

Berlejung, A. (2017). Náboženské dějiny starověkého Izraele. Praha: Vyšehrad.

Biale, R. (1984). Women and Jewish Law, the Essential Texts, Their History, and Their Relevance for Today. New York: Shocken Books Inc.

Biernot, D. (2016). Nástrahy postsekularismu: Židovský fundamentalismus a současná izraelská společnost. Theologická revue 87(3), pp. 133-154.

Budayova, Z. (2021). Measures and assistance for citizens in the field of employment during the pandemic situation of Covid-19 in Slovakia. Revue Internationale des Sciences humaines et naturelles 11(1), pp. 105-119. ISSN 2235-2007.

Craig, G. B., \& Beldman, D. (2017). Deserting the King: The Book of Judges. LexhamPress.

Even-Sosan, A. (2010). Milon Even-Šošan mechudaš u meudkan lišnot ha-alafim: bešiša krachim. Israel: Hamilon hechadaš.

XLinguae, Volume 15 Issue 1, January 2022, ISSN 1337-8384, eISSN 2453-711X 
Gesenius, W. (1962). Hebräisches und aramäisches Handwörterbuch über das alte Testament. Berlin: Göttingen - Heidelberg.

Greenberg, B. (1998). On Women and Judaism: A View from a Tradition. Philadelphia: Jewish Publication Society.

Hlad, L. (2021a). Co-redemption as the essence of the mariology of Pavol M. Hnilica as inspired by the messages of Fatima | [Princíp spoluvykúpenia ako esencia fatimsky inšpirovanej mariológie Pavla M. Hnilicu Historicko-teologická štúdia]. Studia Theologica 23(2), pp. 125-150. ISSN 1212-8570. Doi: 10.5507/sth.2020.054

Hlad, L. (2021b). Hugo Rahner (1900-1968) - prítomnost' jeho kerygmatického odkazu v magistériu a teológii zameranej na novoevanjelizačnú prax. Kerygmatickoludická teologická reflexia. Verba Theologica 20(1), pp. 6-28. ISSN 1336-1635.

Hulbert, B. (2016). Whose Victory Song is it Anyway? The Political and Theological polemic presented in the Song of Deborah. Talbot School of Theology.

Jancovic, J. (2020). Blood revenge in light of the imago dei in genesis 9:6. Its semantics and pragmatics. Biblical Annals 10(2), pp. 191-206. ISSN 2083-222.

Jancovic, J. (2019). Who are addresses of peace in the canticle gloria in excelsis? Analysis of the phrase in luke 2:14 and its translation proposal | [Kto sú adresáti pokoja v chvalospeve Gloria in excelsis? Analýza spojenia v Lk 2,14 a návrh jeho prekladu]. Slavica Slovaca 54(2), pp. 129-141. ISSN 0037-6787.

Janigova, E., \& Pekarcik, L. (2021). Case management as a tool for the inclusion of socially disadvantaged people in society. Revue Internationale des Sciences humaines et naturelles 11(4), pp. 17-26. ISSN 2235-2007.

Keel, O. \& Uehlinger, Ch. 1998. Gods, Goddesses, and Images of God in Ancient Israel. Fortress Press, Michigan.

Kobylarek, A., Alaverdov, E., \& Jakubowska, L. (2021). The significance of a pandemic in teaching foreign languages, with special regard to the teaching of seniors. Xlinguae 14(1), pp. 73-80. ISSN 1337-8384. Doi: 10.18355/XL.2021.14.01.06

Kondrla, P., \& Durkova, E. (2018). Interpersonal relations in ethics of science and technologies. Communications - Scientific Letters of the University of Zilina 20(1), pp. $45-50$.

La Montagne. The Song of Deborah (Judges 5). [online] Disretation. Available: https://www.academia.edu/31151232/The_Song_of_Deborah_Judges_5_Meaning_an d_Poetry_in_the_Septuagint.

Lanoir, C., Romer, T., Macchi, J. D., \& Nihan, Ch. eds. (2020). Kniha Soudců. Úvod do Starého zákona. Geneve/ Jihlava: Labor et fidés.

Maturkanic, P., Tomanova Cergetova, I., Kondrla, P., Kurilenko, V., \& Martin, J. G. (2021). Homo culturalis versus cultura animi. Journal of education culture and society 12(2), pp. 51-58. ISSN 2081-1640. Doi: 10.15503.jecs2021.2.539.549

Ortega-Villasenor, H. (2021a). Kierkegaard and marx: Concurrences for a more harmonious life. Journal of Ethnic and Cultural Studies 8(1), pp. 26-42.

Ortega-Villasenor, H. (2021b). Religionis et societatis, the archaic gaze of reason | Religionis et societatis, la mirada arcaica de la razon. XLinguae 14(3), pp. 75-86. ISSN 1337-8384. Doi: 10.18355/XL.2021.14.03.08

Pavlikova, M. (2019). Existential features of Søren Kierkegaard in modern American Literature. Toronto: Kierkegaard Circle. ISBN 978-1-988129-05-1.

Pipal, B. (2006). Hebrejsko-český slovník ke Starému zákonu. Praha: Kalich.

Rahlfs, A. ed. (1975). Septuaginta. Stuttgart: edition minor.

Roubalova, M., Judak, M., Kralik, R., Slobodova-Novakova, K., \& Maturkanic, P. (2021a). Nejstarší židovský "BEJT HAKNESET" v Praze v kontextu ustanovení halachy. Historia Ecclesiastica 12(1), pp. 9-15. ISSN 1338-4341. 
Roubalova, M., Kralik, R., Maturkanic, P., Biryukova, Y., \& Isskhan, M. (2021b). Basic philosophical ideas associated with the Sabbath. Xlinguae 14(3), pp. 115-126. ISSN 1337-8384. Doi: 10.18355/XL.2021.14.03.11

Roubalova, M., Kralik, R., Tvrdon, M., Tkacova, H., Maturkanic, P., \& Hlad, L. (2021c). Neúmyslné udeření těhotné ženy a jeho právní následky podle Tanachu a Rabínské literatury: Historické a sociologické perspektivy. Verba Theologica 20(2), pp. 82-106. ISSN 1336-1635.

Roubalova, M., Kralik, R., Zaitseva, N. A., Anikin, G. S., Popova, O. V., \& Kondrla, P. (2021d). Rabbinic Judaism's perspective on the first crimes against humanity | [Prvi zločini proti človeštvu z vidika rabinskega judovstva]. Bogoslovni Vestnik 81(1), pp. 57-74.

Shapira, H. (2012). "For the Judgment is God's": Human Godment and divine Justice in the Hebrew Bible and in jewish Tradition. Journal of Law and Religion 27(2), pp. 273-382.

Tsang, S. (2007). Violence and Gender: The Ugaritic „Violent Female“ Tradition and the Deborah Story. SCS, 4.

Webb, B. G. (2012). The Book of Judges: The New international Commentary on the Old Testament. Wm. Michigan: B. Eerdmans Publishing Co.

Words: 4743

Characters: 32252 (17,92 standard pages)

ThDr. Eva Vymetalova Hrabakova, Th.D.

Hussite Theological Faculty Charles University in Prague

Pacovská 350/4,

14000 Praha

Czech Republic

eva.vymetalova@htf.cuni.cz

PaedDr. ICLic. Michal Podzimek, Ph.D., Th.D. (correspondence author)

Department of Philosophy

Faculty of Science, Humanities and Education

Technical University of Liberec

46117 Liberec 1

Czech Republic

michal.podzimek@tul.cz

Assoc. prof. PaedDr. Beata Akimjakova, PhD.

Faculty of Theology

The Catholic University in Ružomberok

03401 Ružomberok

Slovak Republic

beata.akimjakova@gmail.com 